\title{
O direito sob a perspectiva da linguagem, da argumentação e da democracia
}

\section{Law under the perspective of language, argumentation and democracy}

\author{
MARCOS ANTONIO DA SILVA
}

Resumo: Este artigo pretende realizar uma breve contribuição às discussões envolvendo Direito, Política e Filosofia. Essa abordagem é construída diante de temas tão relevantes e profundos como o são os direitos fundamentais, a democracia e o diálogo. Com isso, visa-se cotejá-los e aproximá-los, por meio de um processo metodológico analítico-conceitual, de vocação esquemática, procurando resguardar sempre uma constante interlocução de ideias e pensamentos. Tudo isso dentro do contexto da noção contemporânea de Estado de Direito, sem, contudo, se esquecer das implicações práticas e realistas que devem permear e orientar a investigação de tais disciplinas e categorias.

Palavras-chave: Direito. Linguagem. Argumentação. Democracia.

Abstract: This article intends to make a brief contribution to the discussions involving Law, Politics and Philosophy. This approach is built on themes as relevant and profound as fundamental rights, democracy and dialogue. With this, the aim is to compare them and bring them together, through an analytical-conceptual methodological process, with a schematic vocation, always seeking to safeguard a constant dialogue of ideas and thoughts. All this within the context of the contemporary notion of the Rule of Law, without, however, forgetting the practical and realistic implications that must permeate and guide the investigation of such disciplines and categories.

Keywords: Law. Language. Argumentation. Democracy.

\section{Introdução}

Dessume-se do título do artigo que o texto terá por escopo abordar temas relacionados à linguagem, à argumentação e à democracia em cotejo com o Direito, examinado na atual quadra constitucional, ou seja, no contexto do Estado Democrático de Direito.

Sem ter a pretensão e a ilusão de dar respostas definitivas a assuntos tão complexos e de se chegar a conclusões fáceis e superficiais, mas, conforme se poderá haurir da leitura do conteúdo então elaborado, semear a dúvida e o espírito reflexivo, por meio de método expositivo e analítico, de modo que não se fará tábula rasa para o rigor científico, deveras, exigido pela academia. Em suma, o estudo, nesta ocasião engendrado, não procura jamais - eis que filosófica e cientificamente impossível fechar um círculo. Ao contrário: deixa, intencionalmente, alguns "pontos soltos" para que sejam eles, em certa medida e em ocasiões futuras, melhor aprofundados.

\footnotetext{
${ }^{1}$ Graduado em Direito pela Universidade Estadual do Norte do Paraná - UENP - 2001. Especialização em Direito internacional e econômico pela UEL - 2009. Mestre em Direito pela UENP - 2012. Doutorando em Filosofia pela UEL- 2021. E-mail: marcosasilva789@gmail.com
} 
Construir uma interconexão temática, investigando a existência sólida e definida de um fio condutor entre áreas importantes do Direito, da Política e da Filosofia, é o propósito para o qual se dirige o estudo aqui propugnado.

Direito, linguagem, argumentação, democracia, poder, política e razão são elementos sobre os quais o pensamento Ocidental, desde a Antiguidade, se debruça e com os quais se quer avançar no ideal de vida boa, na acepção defendida por Aristóteles, sem os quais, no entanto, não teria a humanidade chegado aonde chegou, e para os quais a linguagem e a argumentação contribuíram exponencialmente.

O patamar civilizatório, em razão dos avanços e apesar dos retrocessos, é fruto da reflexão em torno desses elementos, de modo que uma discussão, de acordo com a abordagem que a eles se dê, é sempre imperioso e, por que não, produtivo para o que, atualmente, se acostumou a chamar de Filosofia Constitucional, ou seja, para a reflexão voltada para o constitucionalismo, para a constituição e para o direito constitucional (Filosofia, Política e Direito, respectivamente).

A intenção primeira e precípua no debate ora desencadeado é, sobretudo, reacender a fagulha do enfrentamento teórico e dialógico, seja entre ideias, conceitos, elucubrações e estratégias intelectuais de algumas das vertentes do saber jusfilosófico.

A fim de esboçar um desenho esquemático do ensaio proposto, é bom esclarecer, entrementes, que o primeiro capítulo constituirá um enfretamento da relação necessária entre Direito e linguagem, na medida em que aquele se faz conhecido e se impõe mediante as proposições expressas por esta.

No capítulo segundo, procurar-se-á retratar o papel fundamental da argumentação no diálogo com pretensões acerca da emergência em se adotar e elaborar uma construção prática e teórica do Direito, ou seja, tanto na jurisprudência quanto na jurisciência.

Por fim, a questão sobre a democracia abordará o sempre instigante embate entre Direito e Poder, bem como as implicações jurídico-filosóficas que esta intrincada proximidade acarreta. 


\section{Direito e linguagem}

O Direito, fenômeno histórico e cultural, tomado também no seu sentido epistemológico ${ }^{2}$, é linguagem ${ }^{3}$. Esta é de tão fundamental importância para a análise jurídica que, Norberto Bobbio, no seminal artigo Scienza del diritto e analisi del linguaggio, que o tornou, na Itália, "o pai-fundador da lógica deôntica”, consigna que a cientificidade do Direito não está na verdade dos conteúdos, mas no rigor da linguagem (LAFER, 2013, p. 51). Daí a razão pela qual, na esteira no pensamento bobbiano, salienta-se que:

Esses dois cursos (Teoria da Norma Jurídica e Teoria do Ordenamento Jurídico) são pontos altos da análise estrutural do Direito empreendida por Bobbio, no âmbito da qual o Direito é examinado a partir do ângulo interno ao jurídico, e o conceito de ordenamento é visto como a grande contribuição do positivismo jurídico à teoria geral do Direito. Nesse contexto, explica Bobbio, a juridicidade não é uma propriedade das normas na sua singularidade, mas sim do ordenamento como um conjunto estruturado de normas. Essas têm, metodologicamente, a nota própria de um discurso prescritivo, e por isso Bobbio destaca no seu prefácio a importância do Capítulo III (As proposições prescritivas) do (livro) Teoria da Norma Jurídica que expressa o seu recorrente interesse pela análise da linguagem como caminho para o estudo do Direito (LAFER, 2013, p. 161).

Aliás, dada a seriedade científica e imprescindibilidade da linguagem para o Direito, é imperativo dizer que ela, em última instância, é símbolo cultural que, acima de tudo, humaniza, civiliza, sublima e eleva. Com este espírito e com este ideal, pontifica, sabiamente, Louis Hjelmslev (1975, p. 1) acerca da linguagem:

\footnotetext{
${ }^{2}$ A compreensão coerente do estatuto epistemológico do direito continua a ser um dos principais problemas da filosofia jurídica moderna. Discute-se, atualmente, sobre diversos temas que se dizem vinculados à relação observada entre direito e justiça, direito e moralidade, arbitragem e política, direito e poder etc. Sabe-se, igualmente, existir um notório interesse pela caracterização da estrutura lógica das proposições jurídicas, que, como importantes construções lingüísticas, consideram-se elementos basilares do discurso jurídico, isto é, dos contextos doutrinários e normativos. Estudos contemporâneos, geralmente ligados à filosofia analítica, desenvolvem-se com o intuito de esclarecer o caráter descritivo ou prescritivo das proposições do direito. A respeito desses estudos, com frequência, observa-se um razoável interesse pela significação proposicional, por ser considerada uma condição auxiliadora para a compreensão do estatuto epistemológico do direito (SERRANO, 2007, p. 7).

${ }^{3}$ Lenio Luiz Streck (2018), ao defender a normatividade constitucional e ao tecer severas críticas ao solipsismo judicial, à moral e à política, que, para ele, atentam contra o estado democrático de direito e contra a própria autonomia epistemológica do direito, leciona, dada a importância da linguagem para a ciência jurídica, que: direito é linguagem pública. Quando vamos ao judiciário, não perguntamos o que cada magistrado pensa pessoalmente sobre o direito. Não. Perguntamos o que essa linguagem pública tem a nos dizer. Sob pena de o direito perder seu necessário grau de autonomia. Se a moral e a política o corrigem, o que dele resta? E para o quê serve? Para referendar decisões morais e políticas previamente tomadas? Mas então ele só, mesmo, uma teoria política de poder.
} 
A linguagem - a fala humana - é uma inesgotável riqueza de múltiplos valores. A linguagem é inseparável do homem e segue-o em todos os seus atos. A linguagem é o instrumento graças ao qual o homem modela seu pensamento, seus sentimentos, suas emoções, seus esforços, sua vontade e seus atos, o instrumento graças ao qual ele influencia e é influenciado, a base última e mais profunda da sociedade humana. Mas é também o recurso último e indispensável do homem, seu refúgio nas horas solitárias em que o espírito luta com a existência, e quando o conflito se resolve no monólogo do poeta e na meditação do pensador. Antes mesmo do primeiro despertar de nossa consciência, as palavras já ressoavam à nossa volta, prontas para envolver os primeiros germes frágeis de nosso pensamento e a nos acompanhar inseparavelmente através da vida, desde as mais humildes ocupações da vida quotidiana aos momentos mais sublimes e mais íntimos dos quais a vida de todos os dias retira, graças às lembranças encarnadas pela linguagem, força e calor. A linguagem não é um simples acompanhante, mas sim um fio profundamente tecido na trama do pensamento; para o indivíduo, ela é o tesouro da memória e a consciência vigilante transmitida de pai para filho.

Assim, todo o sistema jurídico se estrutura pelo poder e pela força da palavra, isto é, da linguagem, do logos (TRINDADE, 2017, s/p):

Ora, se o Direito é linguagem - e isso me parece trivial, ao menos desde o início do século passado - então contra fatos só há argumentos. E essa é uma razão pela qual os interessados devem prestar vestibular para o curso de Direito e, depois, estudar alguma coisa de filosofia. Isso porque, epistemologicamente, o processo judicial não é formado de fatos, mas de enunciados linguísticos acerca de fatos, como sempre dizem Lenio, Warat, Albano, Cárcova, Calvo González, entre outros.

A maneira pela qual, no Direito, a palavra é aplicada traduz um sentido todo ele peculiar. Sob este enfoque - do Direito como linguagem - no momento em que aborda o Culturalismo Jurídico, cotejando os estudos filosóficos de Miguel Reale, Luís Recasés Siches e Carlos Cossio, Luiz Fernando Coelho (2014, p. 213) esclarece que:

Verifica-se que os respectivos estudos atuais se nucleiam em termos como consenso, decisão e procedimento, cujos referenciais não são normas, porém, formas de experiência social, atos de comportamento conceptualizados em normas jurídicas. Ao tomar esses referenciais para sua definição do direito, os autores restauram o antigo realismo psicológico que identificava o direito nas decisões jurisdicionais, bem como, o realismo linguístico que asseverava ser o direito sua própria linguagem, e a doutrina jurídica sua metalinguagem. Linguagem e metalinguagem também são atos de conduta que se revestem de sentido comunitário.

E conclui o raciocínio, acentuando que: 
Esses posicionamentos aproximam-se, e muito, do realismo culturalista, o qual logrou ultrapassar tanto o psicologismo quanto o neonominalismo da filosofia da linguagem, de resto compatíveis com o culturalismo, visto que decisão e linguagem no contexto social são formas de comportamento intersubjetivo (2014, p. 213).

Nesse contexto, o modo assertivo com que direciona, orienta, constrange, ordena, conforma, coaduna e - acima de tudo - convence, persuade e dissuade, bem como os termos linguísticos com que são colocados, indicam a natureza deontológica do Direito (ALMEIDA, 20o8, p. 498-499).

[...] Alexy afirma que os conceitos práticos se dividem em três grupos: conceitos antropológicos, deontológicos e axiológicos. Conceitos antropológicos são aqueles relativos ao homem - vontade, interesse, capacidade, necessidade, decisão e ação. Os conceitos deontológicos e axiológicos, por sua vez, se diferenciariam apenas a partir do seu conceito deôntico fundamental. $\mathrm{O}$ conceito deontológico fundamental é a idéia de "dever ser", ao passo que o conceito axiológico fundamental é a idéia de "bem".

De fato, cabe asseverar, entretanto, que esta característica não é privilégio apenas do Direito, diga-se. Moral e religião, por exemplo, carregam consigo elementos linguísticos muito próximos aos do Direito, na medida em que determinam comportamentos.

Outrossim, quando se entende o Direito na qualidade de fenômeno ordenador da sociedade, não se deve olvidar o aspecto argumentativo da linguagem - o que será desenvolvido mais profundamente no capítulo seguinte -, tendo em vista, principalmente, a natureza democrática que permeia a vida política e social dos Estados ocidentais contemporâneos, de maneira que é natural que esse fenômeno (ordenador e democrático) dever(ia)á informar o pensamento jurídico em voga.

A possibilidade de justificação racional do discurso jurídico é questão de primacial relevância para a cientificidade do Direito, a qual é imprescindível para a solidez de um Estado Democrático de Direito. Apenas se caracterizam como consensos racionais (e, dentro deles, o jurídico), aqueles passíveis de uma justificação discursiva segundo regras de argumentação (TOLEDO, 2005, p. 48).

Considerem-se, por exemplo, como ponto de partida, os textos legais em sentido amplo, fonte por excelência do Direito, mas que com ele obviamente não se confundem.

Contudo, a experiência político-constitucional dos Estados tem demonstrado que a maneira como se revelam as normas, especialmente as legais, não permitem sua equiparação pura e simplesmente ao Direito. É dizer que, no caso, a lei não é necessariamente sinônimo de Direito, muito menos de justiça (LORA ALARCÓN, 2011, p. 31). 
Neste sentido, a estrutura linguística das construções textuais da lei implica o enquadramento a uma conduta ali idealmente descrita. O famigerado "dever-ser"4 neokantiano e kelseniano (BARACHO, p. 10-11, 15-16):

A referência a Kant é fundamental, pois como acentua Miguel Reale a orientação criticista vem do filósofo alemão, que através dos neoKantianos contribui para a renovação da Filosofia do Direito, de maneira mais acentuada do que qualquer outra corrente, inclusive no domínio do Direito Positivo. No prólogo da segunda edição de Hauptprobleme, Kelsen assinala que o método de sua construção veio do Kantismo, ou melhor, do neo-Kantismo de Marburgo. [...] O modelo de Kelsen tem como objetivo ordenar e esclarecer expressões com as quais labutam os juristas, com indicação dos requisitos que pressupõem em suas exposições dogmáticas, novos conceitos gerais. Para Kelsen esta tarefa requer alguns princípios e categorias como: imputação, dever ser ou norma fundamental hipotética, sem as quais não é possível elaborar uma Ciência Jurídica, nem conhecer o seu objeto, que é o direito positivo. [...] Dentro dessa formulação metodológica e conceitual, o direito é uma ordem do dever ser, no sentido de que não é algo que de fato acontece, é um sistema de normas. Kelsen não persegue a interseção do Direito na realidade, mas como a caracterização conjunta e articulada das normas. A significação formal das normas separa-se da significação justa das mesmas. Com tal objetivo, a Teoria Geral ou Fundamental do Direito tem mais em mira as formas jurídicas, não se ocupando das contendas concretas das regras.

Naturalmente que este "dever-ser" hipotetizado pela lei não redunda, inexoravelmente, no "ser".

Na verdade, o Direito, que constitui o objeto deste conhecimento, é uma ordem normativa da conduta humana, ou seja, um sistema de normas que regulam o comportamento humano. Com o termo "norma" se quer significar que algo deve ser ou acontecer, especialmente que um homem se deve conduzir de determinada maneira (KELSEN, 1998, p. 4).

\footnotetext{
${ }^{4}$ A querela entre "ser" e "dever-ser" na definição da natureza do direito é complexa. Hans kelsen chega a afirmar que existe o direito, que, de um lado, ligado aos juízos de fato, se ocuparia do "ser", ao passo que a ciência do direito, por outro lado, de relativa aos juízos de valor, se voltaria ao "dever-ser". É digna de menção a teoria tridimensional do direito, desenvolvida pelo saudoso professor miguel reale, segundo a qual o direito implica a relação entre fato, valor e norma. Importa, neste contexto, mencionar a elucidativa análise de pablo jiménez serrano (2007, p. 07): porém, nem todo estudioso do assunto reserva para a proposição jurídica o mesmo valor e significado. Assim, por exemplo, alguns autores defendem a idéia de que, no direito, somente existem proposições de tipo prescritivas (normas jurídicas); outros preferem afirmar que, nessa importante área do conhecimento humano, também lidamos com proposições descritivas (ou doutrinárias) e há ainda os que pensam que três são as espécies de proposições jurídicas, pois, ao lado das descritivas e prescritivas, existiriam ainda as valorativas, além de outros importantes recursos, tais como: princípios, aforismos, cláusulas contratuais e regras de direito.
} 
Em outros termos, se a ordem emitida na lei não for rigorosamente observada pelos destinatários, no caso, todo e qualquer indivíduo, em relação a um certo contexto fático na norma prevista, resultará em uma consequência negativamente jurídica contra quem não lhe respeitou os termos impostos, a fim de colocar as coisas no seu devido lugar.

Hans Kelsen procura demonstrar os princípios que orientam esses mundos. Nessa direção, partindo do dualismo de ser (sein) e deverser (sollen), expressa como nos dois se estabelece uma relação polarizada por uma condição e uma consequência. Entretanto, se essa relação no mundo físico ou natural é determinada pela lei da causalidade, no mundo ético ou das relações humanas vigora a lei da imputabilidade. No primeiro, se $A$ (condição) é $B$ (consequência); no segundo, se $A$ (condição) deve-ser $B$ (consequência) (LORA ALARCÓN, 2011, p. 30).

Assim, nunca é demais lembrar que, a reboque da violação, entrarão em cena o poder político soberano do Estado e a questão do monopólio da força. Melhor dizendo, o Estado seria, então, o agente racionalizador, justificador e, por conseguinte, legitimador da violência oficial, física e psíquica (coerção), na elaboração da ordem social.

Em todos os tempos, os agrupamentos políticos mais diversos - a começar pela família - recorreram à violência física, tendo-a como instrumento normal de poder. Em nossa época, entretanto, devemos conceber o Estado contemporâneo como uma comunidade humana que, dentro dos limites de determinado território - a noção de território corresponde a um dos elementos essenciais do Estado reivindica o monopólio do uso legítimo da violência física. É, com efeito, próprio de nossa época o não reconhecer, em relação a qualquer outro grupo ou aos indivíduos, o direito de fazer uso da violência, a não ser nos casos em que o Estado o tolere: o Estado se transforma, portanto, na única fonte do "direito" à violência. Por política entenderemos, consequentemente, o conjunto de esforços feitos com vistas a participar do poder, seja entre Estados, seja no interior de um único Estado (WEBER, s.d. p. 56).

Neste ponto, porém, vislumbra-se o fato de que o Direito é ordem, concebida esta tanto no sentido de organizador, quanto no de mandamento, para cuja manutenção emprega-se, em última análise, caso disso se necessite, o uso da força.

Difícil não resgatar, ilustrativamente, a figura mítica do centauro, mencionada por Maquiavel (2010, p. 78), no capítulo XVIII, de O Príncipe, no qual, para ele, a justiça do governante deve ser metade humana (a cabeça pensante, razão) e metade cavalo (a força bruta).

Também deve ser do conhecimento geral que existem duas matrizes de combate: uma, por meio das leis; outra, pelo uso da força. A 
primeira é própria dos homens; a segunda, dos animais. Contudo, como frequentemente a primeira não basta, convém recorrer à segunda: por isso um príncipe precisa saber valer-se do animal e do homem. Este ponto foi ensinado veladamente aos príncipes pelos escritores da Antiguidade, os quais escreveram como Aquiles e tantos outros príncipes antigos foram deixados aos cuidados do centauro Quíron, que os manteve sob sua disciplina. Isso quer dizer que, tendo por preceptor um ser metade animal e metade homem, um príncipe deve saber usar de ambas as naturezas: e uma sem a outra não produz efeitos duradouros.

Além disso, dentro de uma perspectiva político-filosófica, deve-se levar também em conta a reflexão de Thomas Hobbes e, em certa medida, de August Comte, segundo a qual a noção de justiça coincidiria com a de ordem, o que explicaria e justificaria todas as posturas adotadas pelo poder soberano de plantão (monarca, assembleia ou povo).

Oportunamente, Bobbio afirmava que se quisermos encontrar uma teoria completa e coerente do positivismo jurídico devemos remontar à doutrina política de Thomas Hobbes, para quem não existe outro critério do justo ou do injusto fora da lei positiva, ou seja, fora do comando do soberano. Assim, explica que se para um jusnaturalista uma norma não é válida se não é justa, para o positivista uma norma somente é justa se for válida (LORA ALARCÓN, 2011, p. 38).

Não obstante o caráter imperativo ou impositivo do Direito e sua ambição de ordem e de comando para reger comportamentos, não se deve olvidar, de outra senda, do papel da argumentação na construção da Ciência Jurídica, o que será objeto de análise no tópico seguinte.

\section{Direito e argumentação}

O termo argumentação, segundo o léxico, consiste no ato ou no processo de argumentar, de apresentar um conjunto de argumentos ou de iniciar ou prosseguir em uma discussão ou controvérsia. Com efeito, argumentação seria aduzir ou alegar raciocínios, discutir, altercar.

Aliás, San Tiago Dantas (1948, p. 9), em texto antológico em que analisa a cultura ocidental, sintetiza a relevância humanística do intelecto, da razão e da argumentação, ao frisar que:

Parece-me realmente absurdo que se fosse perguntar a Goethe ou a Cervantes o sentido do Fausto e do D. Quixote, seria supor que essas grandes obras fossem apenas a ilustração de uma tese, preconcebida no espírito do autor. O que considero, porém, legítimo é que se indague do sentido simbólico de qualquer dessas obras; isto é, da significação que cada uma assumiu na perspectiva do tempo, pela operação combinada das intenções do seu autor e da consciência que 
as recebeu. Bem sei que uma grande obra vale e influi, mesmo sem ser integralmente compreendida. Mas a tarefa da inteligência humana é tirar o valor das coisas da obscuridade para a luz.

O homem, no seu simples mister de falar, argumenta. Obviamente que, por se tratar de discurso alusivo ao Direito, está-se falando da argumentação jurídicofilosófica e não da prova matemática.

No século XX Toulmin e Perelman consideraram a argumentação jurídica como modelo para a argumentação filosófica. O âmbito do discurso filosófico é o da verossimilhança e não aquele da certeza, e isso explica o fato de que na argumentação filosófica, diferentemente do caso da prova matemática, a conclusão não é estabelecida de forma definitiva. É por isso que podemos dar vários argumentos a favor de uma mesma tese. Pelo contrário, uma única demonstração matemática bem construída é suficiente. É verdade que, por exemplo, tem sido dadas várias provas diferentes do Teorema de Pitágoras além daquela dada nos Elementos de Euclides. Aliás, poucos matemáticos conhecem a prova dada por Euclides. Mas esse resultado já foi provado por Euclides, de uma vez para sempre. As provas seguintes ou são mais simples ou mais elegantes, mas não têm um valor probatório maior, não têm maior força que aquela dada nos Elementos. Pelo contrário nas Meditações Metafísicas de Descartes encontramos três provas da existência de Deus. E quantos argumentos em favor da imortalidade da alma são dados no Fédon de Platão! Aqui temos uma grande diferença. Na argumentação filosófica a força com a qual é estabelecida uma tese varia segundo o argumento. Vários argumentos diferentes podem concorrer para provar uma mesma tese. Na prova matemática isso não acontece. É supérfluo considerar duas provas do mesmo teorema. Por outro lado, aqui temos só duas situações: ou há prova, se ela está bem construída, ou não há prova, se contém um erro de dedução (MOLINA, 2007, p. 15-16).

Sem embargo, o entendimento acerca do conteúdo normativo dos textos legais, não olvidando, logicamente, a tese de que há diferença entre texto normativo e norma (MÜLLER, 2008, p. 10), demanda uma dose considerável de esforço interpretativo para se chegar ao seu sentido e alcance, máxime se se levar em conta a notória complexidade fática e a realidade constitucional que se abrem ao intérprete quando da aplicação do Direito, o que leva à conclusão de que interpretar não é tarefa fácil e enganosamente óbvia.

Em razão disso, a articulação intelectual, racional e reflexiva do jurista sobre os textos normativos, a cargo da hermenêutica jurídica, no exercício do Direito, é missão instransponível, cujas ferramentas darão os parâmetros necessários à fixação do melhor entendimento a ser dali retirado. Em suma, pode-se afirmar, com toda razão, que argumentar é esforço mental em busca de elementos lógicos para sustentar um discurso. 
Assim, sob tal propósito, não se deve jamais deixar de dar, a rigor, atenção específica, então, à questão fática envolvida nas relações jurídicas e seus contornos específicos que realmente interessam ao mundo do Direito, até porque ela exige também uma leitura interpretativa dos elementos que a constituem.

[...] a necessidade do juiz de pôr a vida em relação com a lei implica uma série de juízos de experiência não só bastante complexos do ponto de vista lógico, mas também inclui aspectos determinantes de natureza valorativa, como a "compreensão" e a "interpretação" tanto da norma quanto da circunstância de fato (ESSER, 1983, p. 49).

Em suma, os fenômenos fáticos carecem de um recorte, de uma delimitação e de uma definição jurídicos, à luz das formas e dos conteúdos da norma posta e pressuposta.

Além do mais, a análise dos preceitos normativos e fáticos se eleva e se destaca na complexidade do exercício argumentativo realizado pelo jurista, incluindo principalmente a atividade desenvolvida no âmbito processual, no qual se dá o enfretamento pelo bem da vida pleiteado, de maneira que, nesse passo, a argumentação é prática constante, melhor dizendo, é exercício vital dos que se envolvem na discussão de temas jurídicos, sob os auspícios do paradigma democrático:

O Supremo Tribunal Federal demonstra, com este julgamento, que pode, sim, ser uma Casa do povo, tal qual o parlamento. Um lugar onde os diversos anseios sociais e o pluralismo político, ético e religioso encontram guarida nos debates procedimental e argumentativamente organizados em normas previamente estabelecidas. As audiências públicas, nas quais são ouvidos os expertos sobre a matéria em debate, a intervenção dos amici curiae, com suas contribuições jurídica e socialmente relevantes, assim como a intervenção do Ministério Público, como representante de toda a sociedade perante o Tribunal, e das advocacias pública e privada, na defesa de seus interesses, fazem desta Corte também um espaço democrático. Um espaço aberto à reflexão e à argumentação jurídica e moral, com ampla repercussão na coletividade e nas instituições democráticas (BRASIL, 2008, s/p).

Ao resgatar-lhe a etimologia, repita-se, nota-se que argumentar significa esclarecer, clarear, iluminar, ou seja, traduz a ideia de lançar luz sobre o que é obscuro, oculto e nebuloso, desatando o nó górdio de uma controvérsia.

Neste sentido, Direito é argumentação, na medida em que a razão ficará do lado de quem, em face dos ditames da norma e dos elementos de fato, tiver a habilidade de melhor compor a linguagem com o objetivo de levar clareza e luz para iluminar as veredas tortuosas pelas quais o julgador deverá percorrer para se chegar à solução constitucionalmente correta. 
Ninguém duvida de que a prática do direito consista, fundamentalmente, em argumentar, e todos costumamos convir em que a qualidade que melhor define o que se entende por um "bom jurista” talvez seja a sua capacidade de construir argumentos e manejá-los com habilidade (ATIENZA, 2014, p. 3).

Argumentação seriam, em rigor, competências de articular expressões linguísticas convincentes, de modo preciso, conciso, claro e objetivo, com o intuito de bem expor os fundamentos da tese daquele que discursa.

Vale lembrar, nesta senda, que argumentar requer pacto fiel à simplicidade de estilo. Parafraseando Ortega y Gasset ${ }^{5}$, a clareza é a cortesia do jurista. Com efeito, a maneira empolada de se expressar é uma armadilha na qual muitos insistem em cair, conquanto tenham consciência de que é pecado mortal para o convencimento e o esclarecimento das ideias.

Arthur Schopenhauer (2009, p. 21), célebre filósofo do Dezenove, em A Arte de Escrever, recriminava quem muito escrevia e pouco dizia, com o infeliz e estéreo anseio de demonstrar uma falsa erudição:

\begin{abstract}
Assim como as atividades de ler e aprender, quando em excesso, são prejudiciais ao pensamento próprio, as de escrever e ensinar em demasia também desacostumam os homens da clareza e da profundidade do saber e da compreensão, uma vez que não lhe sobra tempo para obtê-los. Com isso, quando expõe alguma idéia, a pessoa precisa preencher com palavras e frases as lacunas de clareza em seu conhecimento. É isso, e não a aridez do assunto, que torna a maioria dos livros tão incrivelmente entediante. Pois, como podemos supor, um bom cozinheiro pode dar gosto até a uma velha sola de sapato; da mesma maneira, um bom escritor pode tornar interessante mesmo o assunto mais árido.
\end{abstract}

Ser simples, no entanto, é complexo, na medida em que a arte de se fazer entender, invariavelmente, cobra do jurista refinamento e maturidade intelectual, cuja consecução se obtém com anos de estudo, preparação, disciplina e dedicação: Bobbio, citando uma frase de Balzac, está ciente de que "ao lado da necessidade de definir está o perigo de se embrulhar (LAFER, 2013, p. 51). Assim, está-se autorizado a falar, em certa medida, na noção de Direito como arte, cuja prática, forçosamente, precisa ser cultivada.

\footnotetext{
5 José Ortega y Gasset, em verdade, afirma que "a clareza é a cortesia do filósofo", preceito este nem sempre aplicado pelos pensadores, designadamente os de origem continental: claro es, yo he de hacer el más leal esfuerzo para que a todos ustedes, aun sin previo adiestramiento, resulte claro cuánto diga. Siempre he creído que la claridad es la cortesía del filósofo, y, además, esta disciplina nuestra pone su honor hoy más que nunca en estar abierta y porosa a todas las mentes, a diferencia de las ciencias particulares, que cada día con mayor rigor interponen entre el tesoro de sus descubrimientos y la curiosidad de los profanos el dragón tremebundo de su terminología hermética. (ortega y gasset, 1957, p. o7). (grifo nosso).
} 
Em linha com tais assertivas, sendo a linguagem e a argumentação fulcrais para a construção do Direito e da Democracia, os quais pressupõem a existência dos Direitos dos Homens para a conquista da paz, deve-se anuir que, quem defende um determinado ponto de vista, ao edificar um raciocínio jurídico no atual contexto jurídico-constitucional, deve concatenar argumentativamente a ideia postulada, com a cautela de não haver contradições, redundâncias e termos pedantes, que têm o condão de sabotar o que se quer sustentar. São eles inimigos do discurso argumentativo. Deve-se também ter cautela redobrada com a (vazia e estéril) retórica que, embora na Antiguidade Clássica estava indissociavelmente jungida à argumentação, mas que com o passar do tempo, desta se desvinculou:

A retórica é chamada arte (do latim ars, que traduz o grego techné), porque é um conjunto de habilidades (é uma técnica, entendiam os antigos) que visa a tornar o discurso eficaz, ou seja, capaz de persuadir. Ao longo dos séculos, a retórica foi uma das disciplinas que estavam na base de todo o ensino. No entanto, ela cada vez mais foi sendo entendida como uma técnica de ornamentação do discurso. A palavra ornamentação era entendida como enfeite. Por isso, ela foi perdendo sua dimensão argumentativa e reduziu-se a um catálogo de figuras. Por essa razão, num determinado momento, foi entendida com algo inútil. [...] Na Antiguidade e na Idade Média, o campo dos estudos linguísticos repartia-se em três disciplinas, a dialética, a retórica e a gramática, o trivium dos medievais. [...] Diz Rener que a retórica era definida como a ars bene dicendi (arte do dizer bem, eficazmente), a gramática, como a ars recte dicendi (arte do dizer corretamente) e a dialética, como a ars vere dicendi (arte do dizer com justeza, conforme a verdade) [...]. (FIORIN 6 , 2016, p. 10-13).

\footnotetext{
${ }^{6}$ Advirta-se que o mesmo autor, porém em outra obra (2017, p. 21-22), esclarece melhor a "tumultuada" relação entre argumentação e retórica ao assinalar que: [...] Interessa-nos a ideia de ornatos, que foi entendido como embelezamento da linguagem com figuras, com tropos. A figura era vista como um enfeite e, como tal, desnecessária, como um "luxo do discurso" (cf. Lausberg, 2004: 128, \$ 162). Com isso, esvazia-se a dimensão tropológica da retórica de sua função argumentativa. [...] Tentemos entender o significado do termo em latim. O ornatos latino corresponde ao grego kósmos, que é o contrário do caos. Ornamentum significa "aparelho, tralha, equipamento, arreios, coleira, armadura". No de bello gallico, deve-se traduzir a passagem naves [...] Omni genere armorum ornatissimae (iii, xiv, 2) como "navios equipadíssimos de todo tipo de armas". Isso significa que o sentido inicial de ornatos em retórica não era "enfeite", mas "bem argumentado", "bem equipado para exercer sua função", o que quer dizer que não há uma cisão entre argumentação e figuras, pois estas exercem sempre um papel argumentativo. $O$ ornatos, no dizer de vieira, é a ordem das estrelas, "mas a ordem que faz influência, não é a ordem que faça lavor"(=enfeite). A retórica a herênio diz que a ornamentação serve para realçar, amplificar aquilo que se expõe, ou seja, o ornato é um conjunto de operações enunciativas que atua nos eixos da intensidade e da extensão (exornatio est, qua utimur rei honestandae et conlocupletandae causa, confirmata argumentatione (= o ornamento é o que usamos, após a confirmação, para dar à argumentação relevo $e$ amplitude) (ii, xviii, 28)). Não podemos esquecer-nos de que a palavra argumento é formada com a raiz argu-, que significa "fazer brilhar, cintilar" e que está presente nas palavras portuguesas argênteo, argentário, argento, argentar, argentaria, argentífero, todas provindas do latim argentum, "prata". O argumento é o que realça, o que faz brilhar uma ideia.
} 
Ademais, em defesa da boa argumentação, outro não é o posicionamento doutrinário-científico de Luiz Fernando Coelho (2014, p. 206), referenciando e reverenciando Robert Alexy, ao asseverar que:

A teoria da argumentação jurídica consiste pois numa metodonomologia que articula a teoria do discurso prático, cujas condições de racionalidade procura fixar, com a teoria do sistema jurídico. Essas regras não divergem do que a tradição dogmática tem elaborado; entre outras, a exigência de não contradição; de universalidade no sentido de um uso consistente dos predicados empregados; clareza linguístico-conceitual; verdade das premissas empíricas utilizadas; completude dedutiva do argumento; considerações das consequências; ponderação; e análises da formação de convicções morais.

O viés dialético do Direito induz à inexorabilidade da argumentação e da contra argumentação, de sorte que a justiça possível, a perfectibilidade da justiça, acontece na submissão irrenunciável ao contraditório, curvando-se à argumentação mais plausível e eficiente do discurso propugnado. Neste aspecto, é bem ilustrativo o escólio do agir comunicativo de Jürgen Habermas, quando analisa alguns pontos do pensamento de Robert Alexy, cujo cotejo de ideais foi objeto de explanação por Luiz Fernando Coelho (2014, p. 206) que prontifica que:

As regras do processo discursivo, cogitadas por Alexy, foram albergadas por Habermas, que as resume em duas exigências básicas: primeiro, que todos os que estão aptos a falar podem tomar parte no discurso. Como corolário, todos podem questionar qualquer afirmação em um discurso, introduzir novas afirmações e exteriorizar seus respectivos critérios, desejos e necessidades. Segundo, que nenhum interlocutor pode ser impedido de exercer a salvaguarda de seus direitos previamente fixados, quando dentro ou fora do discurso predomina a força.

Irrefutável, também, para uma teoria da argumentação jurídica, a circunstância de que só o conhecimento jurídico estrito não basta ao exercício argumentativo. A Filosofia, por exemplo, é elemento fundamental na arte de se argumentar juridicamente. É bom que se faça esta advertência.

Ocorre que, não obstante a tentativa de descolar-se da filosofia, as teorias do direito contemporâneo que não se alicerçarem sobre sólidos e consistentes aportes filosóficos estão inevitavelmente fadadas ao insucesso: não há teoria do direito sem que haja filosofia no direito, isso porque, como já referido, a filosofia habita o direito (TRINDADE, 2006, p. 26).

$\mathrm{O}$ arcabouço intelectual de quem discursa argumentativamente tem um peso muito grande. Aportes de outros saberes são altamente eficazes e imprescindíveis para formar uma excelente estratégia argumentativa no campo jurídico. 
Filosofia e direito sempre foram (=deveriam-ser) disciplinas essencialmente conexas: a crença nesta assertiva justifica a abordagem e a leitura desenvolvidas. Uma tentativa de maior aproximação entre essas duas disciplinas, aliás, é o que norteia este estudo. A crença de que a filosofia pode (=deve) servir para imprimir racionalidade ao direito, além disso, é o fio condutor de toda a pesquisa apresentada nas próximas linhas deste artigo (ALVES; OLIVEIRA, 2017, p. 137).

Enfim, o conhecimento e a noção de Lógica, Filosofia, Sociologia, Psicologia e, por que não, Teologia servem ao aperfeiçoamento do Direito, do raciocínio e da argumentação jurídicos, como, por exemplo, no preenchimento valorativo de elementos normativos ditos abertos ou vagos, verdadeiras cláusulas gerais, cujo conteúdo, sentido e alcance, em última instância, se submetem ao crivo do intérprete.

É compreensível, contudo, que a atividade valorativa, fruto dos processos interpretativo e argumentativo, não é ilimitada.

Assim, por exemplo, o constituinte brasileiro fez a opção por um Estado Democrático de Direito com fundamento na soberania, na cidadania, na dignidade da pessoa humana, nos valores sociais do trabalho e da livre-iniciativa e no pluralismo político, consoante art. 1. da Constituição de 1988. A interpretação da Constituição Brasileira necessariamente deve ser pautada na observância desses princípios, sob pena de quebra da ordem constitucional. Agora, em hipótese alguma pode o intérprete livremente optar por determinada interpretação levando em consideração os seus valores pessoais, que neste caso não interessam, pois o que está em jogo é a determinação constitucional (COELHO, 2014, p. 248).

Aliás, o próprio Direito, neste particular, em face da Constituição, delineia o papel do intérprete, impondo contornos conceituais e principiológicos cujas fronteiras não podem ser ultrapassadas, sob pena de inadequação semântica, vale dizer, sob pena de inconstitucionalidade frente aos referencias lá determinados.

A posição que assume o Tribunal Constitucional na estrutura do Estado é de auto-reflexão sobre a ordem jurídica, de maneira a fazer imperar a ordem constitucional. Mesmo sendo considerado pela Lei Fundamental Alemã como órgão jurisdicional, e ao mesmo tempo não se identificar com os Tribunais Ordinários, a Corte Constitucional assume a posição do ente imparcial. O controle da constitucionalidade das leis é, antes de tudo, também um controle técnico, pois os argumentos em torno da suposta inconstitucionalidade envolvem conhecimento específico do direito, e necessitam de reflexão afastada dos embates políticos que norteiam o Parlamento (COELHO, 2014, p. 249).

Aqui entra um aspecto cultural importantíssimo. Os limites hermenêuticos no âmbito da interpretação constitucional encontram amparo na própria linguagem, 
entendida esta como manifestação cultural de um determinado contexto. Podem-se expressar, em certa medida, os limites linguísticos por meio do aforismo cunhado por Ludwig Wittgenstein (1968, p. 111, 5.6): Os limites de minha linguagem denotam os limites de meu mundo. Em outras palavras, os limites dados pela linguagem à interpretação do Direito são dados pelos limites do mundo.

Com isso, os valores que orientam a intepretação jurídica, no caso por exemplo da jurisdição constitucional, sob a perspectiva da linguagem, são os valores insculpidos na Constituição, e não os do intérprete.

Os valores positivados na constituição são objeto de análise pelo Tribunal Constitucional enquanto norma, de maneira que não ocorre interpretação destituída de fundamento jurídico. O Tribunal não trabalha com valores em si, mas valores positivados constitucionalmente, de modo que seu papel na estrutura do Estado não pode ser equiparado de forma simétrica ao do parlamento, de forma a possibilitar a argumentação em torno da ausência de legitimação democrática para o controle da constitucionalidade (COELHO, 2014, p. 248).

Desse modo, levanta-se, ainda, partir desta última citação, o fato de que a argumentação é atividade essencial à compreensão do fenômeno jurídico, sem a qual o Direito renuncia à dinamicidade de sua vocação e não responde às expectativas geradas pelos inevitáveis conflitos advindos de uma sociedade pluralista e democrática.

\section{Direito na gramática da democracia}

Mas, afinal, no que consiste a Democracia? Não basta apenas perquirir acerca da histórica distinção entre a democracia dos antigos comparada à dos modernos, pela qual, grosso modo, na primeira, prevalece a participação direta do cidadão nos atos decisórios da comunidade, e na segunda, a escolha de quem vai tomar as decisões fundamentais para o destino da sociedade política.

Ou seja, na modernidade, o cidadão, via de regra, não decide diretamente sobre as diretrizes normativas que regularão a vida em comum, mas decide sobre quem vai deliberar e decidir sobre elas. Decide quem vai decidir.

Para além dos aspectos da democracia direta e da democracia representativa, deve-se, antes de tudo, elaborar um conceito que orientará o raciocínio dos que se debruçam sobre a relação entre Direito e Poder, de um modo geral, e direitos fundamentais e democracia, de um modo particular, na medida em que, a reboque do pensamento político-filosófico bobbiano, devoto obsessivo da razão humana, existe direito sem democracia, todavia não existe democracia sem direito:

Pode haver Direito sem democracia, mas não há democracia sem Direito, pois esta exige normas definidoras dos modos de aquisição e 
exercício do poder. Daí a defesa que faz Bobbio das "regras do jogo" em $O$ Futuro da Democracia. Nas suas palavras, "a democracia pode ser definida como o sistema de regras que permitem a instauração e o desenvolvimento de uma convivência pacífica". Se a democracia requer a construção jurídica das "regras do jogo" e o Direito é, assim, um meio indispensável para modelar e garantir o "como" da qualidade das instituições democráticas, a razão é um instrumento necessário porque o Direito não é um dado da natureza, pois a noção de "natureza" é tão equívoca que não nos oferece um critério para diferenciar o jurídico do não jurídico (LAFER, 2013, p. 135)

A propósito dessa pertinente reflexão, de alto teor procedimentalista em face de uma concepção de democracia, o próprio pensador italiano lhe constrói primoroso conceito no referido texto O Futuro da Democracia - Em Defesa das Regras do Jogo, se não, vejamos:

Afirmo preliminarmente que o único modo de se chegar a um acordo quando se fala de democracia, entendida como contraposta a todas as formas de governo autocrático, é o de considerá-la caracterizada por um conjunto de regras (primárias ou fundamentais) que estabelecem quem está autorizado a tomar as decisões coletivas e com quais procedimentos. [...] para que uma decisão tomada por indivíduos (um, poucos, muitos, todos) possa ser aceita como decisão coletiva é preciso que seja tomada com base em regras (não importa se escritas ou consuetudinárias) que estabeleçam quais são os indivíduos autorizados a tomar as decisões vinculatórias para todos os membros do grupo, e à base de quais procedimentos (BOBBIO, 1986, p. 17).

Nesta toada, Bobbio, leitor atento de Kelsen, examina a relação Direito e Poder sob uma percepção claramente democrática de que o primeiro deve ter a primazia sobre o segundo, justamente para “domesticá-lo", e não o contrário, consoante a tese levantada por Carl Schmitt sobre a preponderância do poder sobre o Direito, convencido este de que a constituição é nada mais que a vontade suprema do detentor do poder político de um Estado (a inevitável reminiscência à "vontade de poder" nietzschiana não é mera coincidência).

Com efeito, Bobbio e sua visão procedimentalista da democracia comenta a nuances entre legitimidade e legalidade, distinguindo-as sob o critério de que, no que tange à primeira, indaga-se "com que título o poder foi conquistado", justo ou injusto, sendo que, no que se refere à segunda, pergunta-se "como se exerce o poder", obedecendo-se ou não às normas jurídicas.

No jogo político, das relações que buscam manter o equilíbrio de poder, é insofismável a presença de elementos de consenso na faina sisífica da edificação do Estado de Direito. Não obstante o fato de celebrar-se merecidamente o consenso no cenário democrático, o que vale muito, em última análise, para o funcionamento 
adequado das instâncias democráticas no cotidiano, é paradoxalmente o dissenso (BOBBIO, 1986, p. 6o-61):

O pluralismo enfim nos permite apreender uma característica fundamental da democracia dos modernos em comparação com a democracia dos antigos: a liberdade - melhor: a liceidade - do dissenso. Esta característica fundamental da democracia dos modernos baseia-se no princípio segundo o qual o dissenso, desde que mantido dentro de certos limites (estabelecidos pelas denominadas regras do jogo), não é destruidor da sociedade mas solicitador, e uma sociedade em que o dissenso não seja admitido é uma sociedade morta ou destinada a morrer. Entre as mil coisas que a cada dia se pode ler sobre estes problemas, nenhuma me pareceu mais convincente que um artigo de Franco Alberoni, publicado no Corriere della Sera de 9 de janeiro de 1977 e intitulado "Democracia quer dizer dissenso". Alberoni parte de uma mesa-redonda televisionada na qual algumas conhecidas personalidades sustentam que se tem um regime democrático quando se pode contar com o consenso dos consócios, e afirma: "nada disso" - "A democracia é um sistema político que pressupõe o dissenso. Ela requer o consenso apenas sobre um único ponto: sobre as regras da competição", pois por democracia no Ocidente, explica, "entende-se um sistema político no qual não existe consenso mas dissenso, competição, concorrência". Como freqüentemente acontece quando se reage contra um erro, Alberoni caiu no extremo oposto: é evidente que a democracia não é caracterizada apenas pelo dissenso mas também pelo consenso (e não apenas sobre as regras do jogo). O que Alberoni queria dizer (de resto pode-se entender muito bem) é que para que exista um regime democrático não é necessário um consenso unânime, como pretendem que exista por amor ou pela força (mas um consenso obtido pela força pode ainda chamar-se consenso?) os regimes de democracia totalitária, os quais, como o próprio Alberoni afirma com precisão, ao invés de deixarem aos que pensam diversamente o direito de oposição, querem reeducá-los para que se tornem súditos fiéis. Para que exista uma democracia basta o consenso da maioria. Mas exatamente o consenso da maioria implica que exista uma minoria de dissentâneos.

Deve-se asseverar, ademais, que, no atual estágio em que se encontra o debate tendente à constante e infindável construção do Estado Democrático de Direito e ao aperfeiçoamento dos direitos fundamentais, a questão, tanto teórica quanto prática, do Direito como linguagem e argumentação, com vistas ao seu envolvimento com a questão da democracia, é essencial para legitimar o poder soberano do povo na ordem jurídico-constitucional vigente:

Perceba-se como mantendo o princípio da vontade popular a democracia evoluiu na sua prática e conceituação, significando um exercício permanente de afirmação do povo que reina sobre o mundo político, de onde tudo provêm e tudo se absorve, até chegar a um modo de vida instrumental, necessário para impedir formas de 
dominação opressivas na solução das dificuldades próprias do relacionamento humano, promovendo o encontro de interesses divergentes (LORA ALARCÓN, 2011, p. 135).

A realidade de um Estado Democrático de Direito implica a análise do fenômeno jurídico com um novo olhar. Isso a partir de um locus privilegiado de observação científica, tendo em vista, em última instância, o paradigma democrático que inspira as instituições jurídicas hodiernas, no qual a questão da argumentação jurídica, da linguagem e da democracia como regime de governo devem ser colocadas à mesa.

A ideia e o conceito de democracia são realidades consideradas, em certa medida, recentes na história da humanidade, sem se esquecer, porém, da noção flexível, fluída, dúctil e volátil e das peculiaridades com que cada civilização, desde os gregos até hoje, tratou e trata a práxis democrática (BIZZARRO; COPPEDGE, 2017, p. 2):

A democracia é um conceito multidimensional (Munck Verkuilen, 2002) e que se encontra em constante transformação. Ela é também um dos pilares da análise da política desde a Grécia Antiga (Held, 1987), sendo central para a ciência política moderna como disciplina. As diferenças nas perspectivas dos teóricos e cientistas políticos, quando existem, estão normalmente concentradas na definição daquelas que são consideradas as dimensões necessárias da democracia (Coppedge, 2012). Enquanto vários autores defendem a primazia da dimensão eleitoral, ilustrada pela presença de eleições livres, justas e decisivas (Dahl, 1971; Schumpeter, 2013), outros argumentam que regimes políticos democráticos incluem dimensões que se expandem para além dos limites da competição eleitoral (Held, 1987; Lijphart, 1999).

O fato é que, em termos de confronto na arena política, jurídica e filosófica, o fenômeno da democracia sempre vem à tona, posto que se revela questão instransponível para o desenvolvimento da sociedade e do indivíduo, para o reconhecimento e para a implementação dos direitos humanos e dos direitos fundamentais, bem como para o aperfeiçoamento dos valores éticos.

Os valores jurídicos atingem a comunidade como um todo e são jurídicos porque incidem sobre os comportamentos sociais mediante normas jurídicas, cuja aplicabilidade sobre os casos concretos demonstra a opção por certos valores, nas decisões que produziram as normas. É nesse sentido que deve ser entendida a lição de Dworkin, assimilando a doutrina de Roscoe Pound sobre o direito como social engeneering. E colocar a democracia como horizonte inobjetável importa em valorar a liberdade, a igualdade e o exercício da cidadania como valores inerentes ao conceito de democracia (COELHO, 2016, p. 225).

É verdade, também, que a questão do poder político e, por via reflexa, da estruturação dos sistemas jurídicos teve, por longo tempo, sua causa primeira e razão 
última no transcendental, no metafísico, no religioso e na providência de Deus. Ou seja, as sociedades, as civilizações, umas mais outras menos, invariavelmente, embasavam a hierarquia social e política em critérios teológicos: um ente divino é quem tudo orquestrava e é quem tudo ordenava. Em uma crítica ao decisionismo (2014, p. 239-240), Luiz Fernando Coelho deixa transparecer tal raciocínio:

O decisionismo não diverge do normativismo no que tange à procura dos fundamentos racionais da juridicidade, mas interpreta o princípio primeiro como expressão de uma vontade, ainda que de um ente ideal hipostasiado. Neste caso, o decisionismo resgata a tradição escolástica da teoria do poder divino, para substituí-lo pela vontade do povo, pela alma da nação ou pela vontade do soberano. Na verdade, o decisionismo encontrou eco no próprio Kelsen, ao asseverar que toda norma pressupõe uma vontade, real ou ficta.

Neste passo, a ordem social e a jurídica se ajustavam ao que a sabedoria e a infalibilidade divina impusessem. O poder inflexionado pelos reis, imperadores, senhores feudais, clérigos se fundamentava na vontade divina. Eles nada mais eram do que os representantes de e os ungidos por Deus para comandar os povos, razão pela qual, dogmaticamente, não podiam e não deviam ser contestados ou lhes serem feitas quaisquer objeções.

Ao longo da Idade Média, por exemplo, as relações sociais e políticas seguiam o princípio da superioridade de alguns homens, os nobres, em relação aos outros, os camponeses. A crença nessa superioridade estava baseada num valor divino. Deus teria feito os homens diferentes uns dos outros e predestinado o caminho de cada um na Terra. Ainda que nem todas as sociedades tenham passado pelo feudalismo, essa cultura tradicional se enraizou e tornou-se a referência no comportamento dos indivíduos em todos os quadrantes do mundo (SOUZA, 2007, p. 103).

A política, tal qual a entendemos, ficou refém, portanto, desse modo de pensar e de agir, uma vez que a vontade popular, fluída, não era levada em conta nas grandes decisões de ordem política.

Com efeito, no aspecto econômico e social, sobre as relações entre os meios de produção, toma-se, por exemplo, a escravidão, cuja instituição, legitimação e cultivo tinham suas justificativas em sede teológica, haja vista que, sendo a mão de obra escrava extremamente necessária à sustentação econômica de inúmeras sociedades políticas nos mais variados tempos e espaços, era tal prática moralmente tolerada e socialmente imposta, mas que, para tanto, deveria ter uma razão, uma racionalidade, uma explicação crível, qual seja, a vontade divina. Enfim, a tradição política, econômica, social, filosófica e jurídica era toda ela erigida a partir do teológico, de Deus, do transcendental e do metafísico. 
Mas, no escravagismo, o mando direto do senhor sobre o servo podiase constituir também junto com uma justificativa edulcorada, que não revelava a verdade de suas causas sociais. Em alguns povos, diziase que o senhor manda no escravo porque Deus o quis. As explicações míticas ou religiosas serviram, muitas vezes, como legitimação da ordem de dominação. Por isso, pode-se ver na Bíblia, por exemplo, Javé fazendo uma aliança com o povo hebreu, dando-lhe favoritismo, e o povo hebreu dizendo que era seu direito fazer a guerra contra o estrangeiro para garantir seu território sagrado, ou então que tinha o direito de esperar os favores de Javé (MASCARO, 2013, p. 18)

No campo político, a investidura de reis, imperadores e tiranos, a seu turno, se explicava, única e exclusivamente, pela hipótese da pura escolha divina. Se se aplicássemos tal paradigma até recentemente, a ascensão ao poder político do Estado de figuras como Napoleão Bonaparte, Hitler, Mussolini, Stálin, Mao Tsé-Tung, Pol Pot teria fundamento religioso.

[...] A dominação dos senhores feudais dava-se, muito mais, com base na pura vontade senhorial que se impunha em face da vassalagem, na tradição, no domínio exclusivo e hereditário da terra. O vínculo de exploração feudal se valia, ainda, de argumentos religiosos, como o da vontade de Deus de que o senhor e o servo assim se mantivessem, e, num plano geral, o que se queira chamar por direito medieval acabava por ser, então, uma forma de raciocínio religioso a benefício dessa dominação. [...] Não havia elementos como o Estado, a circulação mercantil, a exploração do trabalho de maneira assalariada, que distinguem e forma o direito moderno. Pelo contrário, em sociedades de economia escravagista ou feudal o que mais se verifica é o domínio direto, de senhor para escravo, de senhor para servo, do chefe da tribo ou do grupo em relação aos seus. A força física, a violência bruta, a guerra, a tradição, a religião, os mitos, a posse direta da terra, são eles que fazem o papel daquilo que modernamente chamamos por direito (MASCARO, 2013, p. 20).

Entretanto, para nós ocidentais, com o advento do Renascimento, da Reforma Protestante e do Iluminismo (arte, religião e filosofia), rompe-se este cordão umbilical que alimentava as sociedades com a provisões divinas para a Política e para o Direito. Em outras palavras, a doutrina organicista, de cariz aristotélica, cujo exercício do poder era justificado descendentemente, é dizer, de cima para baixo (ex parte principis), foi substituída, desde Thomas Hobbes, pela implantação do modelo contratualista, de base racionalista, em que o poder é legitimado ascendentemente, de baixo para cima (ex parte populi).

Ao se definir que os homens são racionais, livres e iguais, torna-se impossível aceitar um fundamento para o poder que não esteja na própria razão. Por que temos que aceitar a autoridade? Por que se submeter ao poder do Estado? A modernidade descarta a resposta que apelava para Deus ou outra entidade metafísica. A imposição da vontade pessoal do rei como efeito da sua diferença natural 
referendada por Deus não será mais aceita. A existência do poder passa a ter como alicerce o argumento racional de que este é o único caminho para construirmos a convivência pacífica. $\mathrm{O}$ mais importante é que a legitimidade do poder também se pretende racional, o poder aceitável passa a ser aquele fundado no consentimento coletivo, ou seja, na vontade geral. Nesse sentido, os modernos abrem mão de fundar a convivência coletiva em valores transcendentais, de caráter religioso ou não. A percepção é de que toda tentativa de encontrar o bem supremo a partir do qual derivassem as regras para a conduta dos homens redundou em autoritarismo ou violência generalizada. A busca pela verdade moral definitiva só pode resultar, segundo o pensamento moderno, numa eterna e perigosa disputa. Diante desse fato, os modernos deixam de lado a busca pelo "fim" (o bem transcendental) e valorizam os "meios" (procedimentos democráticos) para a convivência pacífica entre homens racionais, livres e iguais. A modernidade restabelece a divisão entre a esfera pública, espaço das disputas políticas e da construção dos interesses comuns; e o mundo privado, dimensão das escolhas valorativas a partir das perspectivas individuais e de pertencer a diferentes grupos, como a família, as associações religiosas, os clubes etc. As instituições do público e do privado comunicam-se, de modo possível e necessário, considerando-se a diferença entre as duas dimensões (SOUZA, 2007, p. 23-24).

Nota-se, a partir de então, que o poder - Política e Direito - se estrutura, ou deveria se estruturar, com elementos construídos e engendrados pelo homem e pela sociedade, razão pela qual o pensamento filosófico de Nicolau Maquiavel, John Locke, Thomas Hobbles, Immanuel Kant, Montesquieu e Jean-Jacques Rousseau renovou e potencializou novas discussões acerca do exercício e da legitimidade do poder político, bem como da natureza do Direito, sem o ranço e a influência transcendental da religião.

Neste contexto, renasce, a toda força, o discurso relativo à vontade popular, de um modo geral, e à Democracia, de uma forma particular, na medida em que a narrativa teológica do Absolutismo não mais se explica e se justifica racionalmente. O povo e os indivíduos, dentro da lógica política e econômica liberal-burguesa, passam a ser senhores de seus destinos políticos, passam a ser emissores e destinatários das normas por eles mesmo elaboradas, de modo que jamais se deve olvidar, todavia, de que Liberalismo não significa Democracia, são dois conceitos, embora historicamente interligados, que não se confundem.

Em outras palavras, superam-se o teológico, o místico, o transcendental e o metafísico, como fundamento da ordem social, econômica, política e jurídica, e se reconhece a soberania popular como novo paradigma. Com isso, tanto mazelas e retrocessos, quanto benefícios e avanços, são debitadas e creditadas na conta das instituições exclusivamente humanas, cujas decisões devem ser tomadas em respeito à decisão democrática da maioria. E sendo o Direito parte dessas instituições 
humanas, tem sua razão de ser unicamente vinculada à manifestação da vontade secular, em respeito também a esta mesma decisão da maioria.

Neste aspecto, se se tomar como ponto de partida a Revolução Francesa, fato histórico que materializou os ideais iluministas defendidos pela burguesia ascendente, o tema Democracia, sem embargo da experiência grega na Antiguidade, começa a desafiar o pensamento político Ocidental com mais vigor.

Democracia, em certa medida, chama a atenção pela circunstância de que o emissor e o destinatário das normas sociais, melhor dizendo, das regras do jogo, se confundem na mesma pessoa: o povo. Talvez, esta perspectiva é que torna a democracia o regime pelo qual os agentes envolvidos no processo político devam agir sob a égide e sob a vigilância implacável da responsabilidade, na medida em que, em última análise, os ônus e os bônus das decisões democráticas, para o bem e para o mal, recaem sobre os ombros do titular do poder: o povo.

A vitória do pensamento democrático, com efeito, expressa o triunfo do constitucionalismo ocidental, da constituição e do direito constitucional. Em outras palavras, não se deve negar que as grandes conquistas, que foram objeto do processo de positivação constitucional, em relação aos direito humanos e aos direitos fundamentais da pessoa humana, transitam mais despreocupadamente sobre o pavimento engendrado pelo esforço democrático e pela estabilidade gerada pela Democracia, tendo em vista que as liberdades públicas potencializam o aperfeiçoamento desse regime de governo, num círculo virtuoso constante, cuja quebra causaria enormes prejuízos à harmonia e ao equilíbrios da relações políticas, sociais e jurídicas.

Neste sentido, é forçoso recorrer, entretanto, que os princípios democráticos necessitam para sua estabilização da existência do Estado de Direito, na medida em que, lembrando Norberto Bobbio, conquanto haja Direito sem Democracia, não há Democracia sem Direito, de modo que aquela requer normas bem definidas, as chamadas "regras do jogo", para a aquisição (legitimidade) e o exercício (legalidade) do poder político (LAFER, 2013, p. 135).

Ao contrário do que propugnava Carl Schmitt, cujas ideias eram no sentido de que a Política é que, em última análise, determinava e fundamentava o Direito, no jogo democrático, kelsenianamente raciocinando, é o Direito que tem primazia sobre a Política. É o Direito que domestica o poder político, limitando-o.

A ruptura entre Política, Direito e o Teologia, levada a efeito no ocaso do século XVIII, trouxe a reboque, como já se disse, o encargo da responsabilidade. Os erros e os acertos cometidos não podem mais ser imputados ao ser espiritualmente superior. A democracia tem o mérito de fazer que cada indivíduo e a coletividade, ao reivindicar e implantar direitos, deve também - e sobretudo - assumir compromissos, ônus, 
obrigações e deveres para consigo e para com o grupo. É-se responsável por si e pela sociedade.

Com a emancipação, o Direito passou a ser o instrumento de controle social legitimado pelo capitalismo. É dizer, o que garante as relações de mercado, o contrato e a exploração do trabalho é Estado moderno por meio das instituições jurídicoburguesas perpetradas no seio do novel agente político.

Essa nova realidade do Direito, que mantém sistematicamente a interconexão com outros ramos do conhecimento humano - a própria Constituição Federal de 1988, tributária dos ventos democráticos que sopraram na Europa pós-Segunda Guerra Mundial, constata a ocorrência da interface com setores e fenômenos até então recebidos com certa reticência pela dogmática jurídica - procura, agora, soluções que, em razão da tradição juspositivista e kelseniana, antes não eram justificadas pela Ciência Jurídica. Porém, deve-se atentar para a seguinte ponderação:

A análise constitucional contemporânea deve estar atenta às características da sociedade atual, pluralista e democrática. Por essa razão, considerar os valores políticos e sociais na interpretação constitucional constitui uma forma de processo legitimador da ordem constitucional e instrumento hábil de avaliação contínua do exercício do poder constituído. Esse tipo de interpretação, entretanto, não pode deixar-se levar de roldão por métodos zetéticos, onde a necessária contribuição das ciências sociais para $\mathrm{o}$ entendimento do fenômeno do direito, acabe substituindo a especificidade da dogmática jurídica. O recurso a valores políticos é legítimo, na medida em que sejam valores positivados, integrados no conteúdo da norma constitucional, mas não será legítimo se encarados na relatividade do momento histórico, na medida em que expressam diretrizes de forças políticas hegemônicas (COELHO, 2014, p. 249).

Exemplo disso é o tratamento dispensado aos princípios jurídicos. Antes, no auge e na hegemonia positivistas, exerciam apenas função subsidiária à norma posta, relegados a tarefas eminentemente secundárias e coadjuvantes do processo jurídicocientífico. Agora, alçado ao status de otimizador e corregedor do ordenamento jurídico, prevalecendo, em certos casos e em certa medida, sobre regras jurídicas discutidas, deliberadas e aprovadas pelos que foram, legitimamente, investidos pelo poder popular, passaram a ser referência central para a racionalidade do desenvolvimento científico do Direito.

Esta superação paradigmática, do positivismo ao pós-positivismo, vem ao encontro da complexidade da vida contemporânea e da busca plural da felicidade, com seus meios peculiares de vida e de contemplar o mundo, as quais desafiam o operador do Direito em seu mister, eis que se torna necessário alcançar respostas que, não raro, fogem ao âmbito puramente jurídico-dogmático-legal-positivista. 
Neste sentido, a multidisciplinaridade ou interdisciplinaridade tem, sem embargo das críticas, sido suscitada para nortear os desafios impostos. Logicamente, o debate acerca dessas questões não se restringe ao momento pré-jurídico, ao âmbito das discussões legislativo-parlamentares. No âmbito da interpretação e da aplicação do Direito deve-se recorrer a conceitos, a aportes e a institutos que, muitas vezes, não foram incorporados à seara jurídica.

Parece não haver dúvida de que o positivismo - compreendido lato sensu (ou seja, as diversas facetas do positivismo) - não conseguiu aceitar a viragem interpretativa ocorrida na filosofia do direito (invasão da filosofia pela linguagem) e suas conseqüências no plano da doutrina e da jurisprudência. Se isto é verdadeiro - e penso que é - a pergunta que cabe é: como é possível continuar a sustentar o positivismo nesta quadra da história? Como resistir ou obstaculizar o constitucionalismo que revolucionou o direito no século XX? Entre tantas perplexidades, parece não restar dúvida de que uma resposta mínima pode e deve ser dada a essas indagações: o constitucionalismo - nesta sua versão social, compromissória (e dirigente) - não pode repetir equívocos positivistas, proporcionando decisionismos ou discricionariedades interpretativas (STRECK, 2010, p. 159).

Com efeito, Ética, Política e Direito entrecruzam-se e dialogam-se na busca de soluções que melhor se aproximam do conceito de justiça. Em outras palavras, as decisões judiciais, por conta principalmente do exercício da jurisdição constitucional que, na atual quadra, interpreta, integra e aplica as normas jurídicas dos mais amplos espectros, tendo em vista o caráter de cláusula geral que, invariavelmente, as permeia, se socorrem da Ciência e da Filosofia Política, da Economia, da Antropologia e da Sociologia, para dar respaldo constitucionalmente adequados ao caso concreto submetido, cotidianamente, ao Estado-juiz.

Neste cenário, o operador do Direito, advogados, juízes, procuradores, promotores de justiça, defensores públicos, professores universitários, enfim, todos os envolvidos no aperfeiçoamento do Direito como ciência e como instrumento de avanço social, devem estar atentos às novas exigências e aos novos paradigmas propostos pelas mais diversas comunidades que compõem o todo social, bem como detectar as angústias e os anseios políticos em torno de determinados temas morais, éticos e jurídicos.

Assuntos polêmicos, naturalmente, estão longe - muito longe - de um consenso pleno e unânime, uma vez que, quando surge um consenso parcial ou provisório sobre algo, novos assuntos se tornam polêmicos - e às vezes mais polêmicos que os anteriores, o que, de resto, demandará mais e mais discussões, dissensos e tensões nos locais públicos de debate. Eis a essência da democracia. 
Se o consenso definitivo é inalcançável e se estamos condenados a viver em meio ao conflito, é a tolerância política que faz da política democrática uma atividade permanente. É ela que obriga os indivíduos a argumentar, deliberar e assumir responsabilidades permanentemente [...] (CITTADINO, 2009, p. 88-89)

Portanto, é imperioso, ao fundamentar uma tese ou decidir um caso específico, fixar alguns parâmetros e justificações que cheguem perto de atender, senão ao consenso máximo, pelo menos ao "consenso mínimo" possível, a fim de conciliar as diversas tendências.

A possibilidade de justificação racional do discurso jurídico é questão de primacial relevância para a cientificidade do Direito, a qual é imprescindível para a solidez de um Estado Democrático de Direito. Apenas se caracterizam como consensos racionais (e, dentro deles, o jurídico) aqueles passíveis de uma justificação discursiva segundo regras de argumentação (TOLEDO, 2005, p. 48).

Ora, uma postura como esta requer conhecimentos amplos não só jurídicos, dogmáticos, normativos, mas também outros saberes, sem os quais qualquer fundamentação, por técnica e juridicamente perfeita que seja, não satisfará, plenamente e a contento, os ditames constitucionais consubstanciados no artigo 93, IX, CF/88, de modo que não se estará observando, com rigor, o princípio democrático que orienta as ações de todos os agentes políticos, entre os quais - e sobretudo - os juízes, cuja investidura e cujo exercício da função jurisdicional, a princípio, estão sob o constante questionamento do déficit democrático, o qual, todavia, pode ser institucionalmente neutralizado com critérios e elementos incluídos, explícita e implicitamente, no texto constitucional e nas decisões proferidas pela Suprema Corte brasileira.

Essa tarefa, porém, revela-se duríssima, mas ao mesmo tempo, eloquente, em certa medida, uma vez que expressões como direitos humanos, direitos fundamentais, dignidade da pessoa humana, liberdade, igualdade, Estado Democrático de Direito, fazem o intérprete mergulhar em um vasto e profundo oceano de possibilidades práticas e teóricas, que colocam o sistema jurídico dentro de um estado constante de instabilidade e insegurança, dada a fluidez desses conceitos.

Portanto, nota-se que o Direito, em particular o Direito Constitucional, é processo constante de construção histórica e cultural que demanda diálogo permanente com os fatores do mundo da vida, seus valores, seus anseios e seus dilemas, de forma que a linguagem, a argumentação e o espírito democrático exercem papel fundamental na estruturação desse grande complexo chamado Direito. 


\section{Considerações finais}

A primeira conclusão a que se chega, à luz do que se discorreu no texto, é a de que Direito e linguagem são conceitos intrinsecamente conectados, de tal modo que fica impossível imaginar, dentro de uma fenomenologia da cultura, um sem a outra. Aliás, é a linguagem elemento fulcral no sentido de que haja um constrangimento epistemológico do Direito, isto é, a linguagem torna-se-lhe indispensável para o próprio rigor científico, demarcando-lhe o amplo espaço a ele dedicado no quadro geral das ciências.

Verificou-se, por outro lado, no desenvolvimento desta exposição teórica, que, à semelhança da linguagem, a argumentação, para o Direito, detém um papel fundamental no aperfeiçoamento das instituições e dos conceitos jurídicos, na medida em que, instrumento e fruto da razão, colabora com as mais variadas construções teóricas e encontra caminhos e soluções para os vários aspectos práticos que, a todo instante, instiga o jurista diante de tais desafios.

Por fim, há de se destacar que Direito, linguagem e argumentação são mecanismos essenciais para a construção, manutenção e consolidação do processo democrático, uma vez que "não há democracia sem direito", pode-se disso deduzir também que não há direito sem linguagem e argumentação, de maneira que tais elementos encerra um importante círculo na constante luta travada, há muito na História da humanidade, de “domesticação” do poder e na efetivação da Justiça.

\section{Referências}

ALMEIDA, F. P. L. Os princípios constitucionais entre deontologia e axiologia: pressupostos para uma teoria hermenêutica democrática. In: Revista Direito GV. São Paulo: Jul./Dez. 2008.

ALVES, F. B; OLIVEIRA, G. F. Entre o esquema sujeito-objeto e o esquema sujeito-sujeito: considerações sobre um novo paradigma. In: Revista de Estudos Constitucionais, Hermenêutica e Teoria do Direito (RECHTD - Unisinos). São Leopoldo: mai./ago. 2017.

ATIENZA, M. As razões do direito: teoria da argumentação jurídica. Trad. Maria Cristina Guimarães Cupertino. 2 ed. Forense Universitária: Rio de Janeiro, 2014.

BIZZARRO, F; COPPEDGE, M. Variedades da democracia no Brasil. Revista Opinião Pública, vol. 23: Campinas, SP, jan./abr. 2017. Acesso em: 18.09.2017. Disponível em:

http://www.scielo.br/pdf/op/v23n1/1807-0191-op-23-1-00o1.pdf.

BOBBIO, N. O futuro de democracia: uma defesa das regras do jogo. Trad. Marco Aurélio Nogueira. Rio de Janeiro: Paz e Terra, 1986.

BRASIL. Supremo Tribunal Federal. ADI/3510 - Ação Direta de Inconstitucionalidade. Relator Ministro Carlos Britto. Julgamento em 28/05/2008.

CITTADINO, G. Pluralismo, direito e justiça distributiva: elementos de filosofia constitucional contemporânea. Rio de Janeiro: Lumen Juris, 2009.

COELHO, L. F. Direito constitucional e filosofia da constituição. 3. ed. Curitiba: Juruá, 2014. 
DANTAS, S. T. D. Quixote: um apólogo da alma ocidental. Brasília: Ed. Universidade de Brasília, 1997.

ESSER, J. Precomprensione e scelta del metodo nel processo di individuazione del diritto. Tradução de Salvatore Patti e Giuseppe Zaccaria. Camerino: Edizioni Scientifiche Italiane, 1983.

FIORIN, J. L. Argumentação. 3. ed. São Paulo: Contexto, 2017.

. Figuras de retórica. São Paulo: Contexto, 2016.

HJELMSLEV, L. Prolegômenos a uma teoria da linguagem. São Paulo: Perspectiva, 1975.

KELSEN, H. Teoria pura do direito. Trad. João Baptista Machado. 6 ed. São Paulo: Martins Fontes, 1998.

LAFER, C. Norberto Bobbio: trajetória e obra. São Paulo: Perspectiva, 2013.

LORA ALARCÓN, P. J. Ciência política, estado e direito público: uma introdução ao direito público da contemporaneidade. São Paulo: Verbatim, 2011.

MAQUIAVEL, N. O príncipe. Trad. Maurício Santana Dias. São Paulo: Companhia das Letras: 2010.

MASCARO, A. L. Introdução ao estudo do direito. 4 ed. São Paulo: Atlas, 2013.

MOLINA, J. A. Lógica e argumentação filosófica. In: Barbarói. Santa Cruz do Sul: jan./jul. 2007.

MÜLLER, F. Teoria estruturante do direito. Trad. Peter Naumann; Eurides Avance de Souza. São Paulo: Revista dos Tribunais, 2008.

ORTEGA Y GASSET, J. ¿Que és filosofía? Madrid: Revista de Occidente en Alianza Editorial, 1957.

SCHOPENHAUER, A. A arte de escrever. Trad. org. pref. e notas Pedro Süssekind. Porto Alegre: L\&PM, 2009.

SERRANO, P. J. Epistemologia do direito: para uma melhor compreensão da ciência do direito. Campinas: Alínea, 2007.

SOUZA, N. R. Fundamentos da Ciência Política. Curitiba: IESDE Brasil, 2007.

STRECK, L. L. Aplicar a "letra da lei" é uma atitude positivista? In: Revista NEJ - Eletrônica. Vol. 15. N. o1. Itajaí, jan./abr. 2010.

Presunção de inocência e juiz natural: um dia os textos vão revidar! Disponível em:

https://www.conjur.com.br/2018-fev-o8/senso-incomum-presuncao-inocencia-juiz-naturaldia-textos-revidar. Acesso em: 08.02.2018.

TOLEDO, C. Teoria da argumentação jurídica. In: Veredas do Direito. Vol. o2. N. o3. Belo Horizonte, jan./jul. 2005.

TRINDADE, A. K. A filosofia no direito: com Gadamer, contra Habermas, à procura de um paradigma de racionalidade a partir do qual seja possível pensar pós-metafisicamente a teoria do direito contemporâneo. São Leopoldo, RS: Universidade Vale dos Sinos, 2006 [Dissertação de mestrado].

. Se direito é linguagem, então contra fatos só há argumentos. Disponível em: http://www.conjur.com.br/2017-jul-15/diario-classe-direito-linguagem-entao-fatosargumentos. Acesso em: 16.07.2017. 
SILVA, M.

WEBER, M. Ciência e política: duas vocações. Trad. Leônidas Hegenberg e Octany Silveira da Mota. São Paulo: Cultrix, s.d.

. Ensaios de sociologia. 5 ed. Rio de Janeiro: Zahar, 1982.

WITTGENSTEIN, L Tractatus logico-philosophicus. Trad. José Arthur Giannotti. São Paulo: USP, 1968.

ZACCARIA, G. Ermeneutica e giurisprudenza, saggio sulla metodologia di Josef Esser. Milano: Giuffrè, 1984.

Submissão: 25. 04. 2021

/ $\quad$ Aceite: 20. 08. 2021 